\title{
Analyzing Social Policy Argumentation: A case study on the opinion of the German National Ethics Council on an amendment of the Stem Cell Law
}

\author{
FRANK ZENKER
}

University of Lund

Department of Philosophy \& Cognitive Science

Kungshuset, Lundagard

22222 Lund, Sweden

frank.zenker@fil.lu.se

\begin{abstract}
This paper analyzes and evaluates the 2007 majority opinion of the German National Ethics Council which seeks to establish new information (as to the inferior quality of legally procurable human embryonic stem cells) as a sufficient reason for a relaxation of the 2002 Stem Cell Law. A micro-level analysis of the opinion's central section is conducted and evaluated vis $\grave{a}$ vis the strongest known opponent position in the national debate at that time. The argumentation is claimed to rely on an unsupported semantic assumption regarding the parthood relation of the 2002 compromise and to misconstrue the strongest known opponent position.
\end{abstract}

Resume: J'analyse et évalue l'opinion majoritaire du Conseil National d'Étique allemand de 2007 dans laquelle il tente d'établir que des renseignements nouveaux (concernant la qualité inférieure des cellules souches embryonnaires qui peuvent être obtenues légalement) suffisent pour mitiger la loi de 2002 ces cellules. J'analyse et évalue très minutieusement la section principale de l'opinion majoritaire en relation avec la meilleure opposition qui s'est exprimée dans le débat national à cette époque. L'argumentation repose sur des suppositions sémantiques non appuyées en ce qui concerne la relation de ce qui constutue une partie dans le compromis de 2002 et sur une mauvaise interprétation des meilleures positions opposées.

Keywords: conductive argument, ethical dilemma, human embryonic, political compromise, political decision, pro/con argument, revision, stem cell research.

(C) Frank Zenker. Informal Logic, Vol. 30, No. 1 (2010), pp. 62-91. 
The compromise represented by the Stem Cell Law consti-tuted a legally based attempt to resolve a conflict on which society was morally divided.

German National Ethics Council (2007: 13)

\section{Introduction}

Modern democracies arguably rely on expert knowledge. Normally giving an expert body a reasonable amount of resources should put them into a significantly better position that a layperson who is constrained by time and lack of information. It therefore seems reasonable to assume that their argumentation would be of demonstrably high quality. Vis à vis this assumption, we conducted a microlevel analysis of the 2007 majority argumentation of the German National Ethics Council (NEC) (the state advisory body for ethical issues) regarding an amendment of the 2002 Stem Cell Law. If our analysis is accepted, the above assumption deserves to be questioned.

In the remainder of this section, we motivate our topic and provide legal background, followed by an outline of our method (Section 2), of the pro/con constellation for this issue (3), and a summary of the opinion under study (4). Analyzing its central section in greater detail (5), we provide an evaluation (6), a brief general discussion of compromises (7), and conclude with a summary (8).

Ever since the feasibility of human embryonic stem cell research (hESCR) had been announced in Thompson et al. (1998), immense practical benefits for future medical therapy have been claimed. As hESCR "consumes" a human embryo (a fertilized egg cell), its moral permissibility has been subject to wide ethical and political debate. In turn, all modern democracies have restricted this kind of research.

While diverging policies were adopted internationally, the German debate on consumptive embryo research and its legislative result have remained peculiar (Beckmann 2004, Braun 2005, Curzer 2004, Geyer 2001, Knoppers et al. 2008, Krones 2006, Schmidt et al. 2004). Up to 2002, public and parliamentary debate had not resulted in a consensus on the ethical and legal permissibility of hESCR. Given the absence of a Rawlsian reflective equilibrium, and the debate about the legal status quo on $\mathrm{hES}$ cells, the Embryo Protection Law (Embryonenschutzgesetz) of 1990 prohibited in vitro fertilization, and a fortiori the frozen-state suspension of the excorporeal embryo's natural development, for purposes other than artificially inducing pregnancy. Thus, by prior 
law (lex anterior), the derivation of stem cells from fertilized pronuclei was illegal. However, their import and research use remained unregulated and so were not criminal acts (nullum crimen sine lege). ${ }^{1}$ Arising as a political compromise between polarized opinions, the 2002 Stem Cell Law qualified legally importable hESC lines for purposes of research to those "harvested" before 2002.

The Stem Cell Act permits the importing and research use of hESC under certain conditions, namely if 1) there is scientific evidence that the research concerned serves "high-priority research goals either in an area of fundamental research ("Grundlagenforschung") or in the enlargement of medical knowledge of diagnostic, preventive, or therapeutic procedures in human medicine" (principle of high priority) (article 5, section 1), and 2) such research, having already been attempted as far as possible in vitro and in vivo in the animal model, can be advanced only by using embryonic stem cells (principle of absence of alternatives) (article 5, section $2 \mathrm{a} / \mathrm{b}$ ). Only if these two principles are respected may a research project be qualified as "ethically admissible" (article 6, section 4/2). If it is so qualified, hESC may be imported and used for research provided 1) they were derived from embryos created for reproductive purposes by in vitro fertilization and left over ("supernumerous") for reasons related not to themselves but to the donor; 2) they have been freely given by their parents for research purposes without honorarium or other benefit; and 3) they were derived from embryos before January 1, 2002 (so as to ensure that these embryos were not killed for the purpose of exporting their stem cells to Germany). (Beckmann 2004: 609)

These conditions (high-priority research, absence of alternatives, derivation prior to 2002) result from balancing interests, as is characteristic of deliberative democracies.

In a 2008 amendment to the Stem Cell Law, the so-called cutoff date for the legal import of hESC lines into Germany has shifted from 1 January 2002 to 1 May 2007. Moreover, the scope of the criminal ban on research with hES cells obtained after the cut-off date has been explicitly restricted to national territory. Presented to the lower house of parliament (Bundestag) as a "political decision in an irresolvable ethical dilemma" (Röspel

1 See Stark (2007: 641f). According to the dominant legal interpretation in Germany, the Stem Cell Law protects an embryo's stem cells only when imported, thus (merely) strengthens the protection afforded by the embryo protection law. This stance is also adopted by Merkel, as a legal expert to the Committee on Education, Research and Appraisal of the Consequences of Technology in March 2008 (CERACT 2008), and presented to parliament as the standard legal interpretation in April 2008. 
2008: 16308), "updating" the Stem Cell Law (i.e., shifting the cutoff date ahead) had been a policy option at least since 2006. In 2007, however, an update was endorsed only by one of two minority positions in the NEC. The majority favored a farther reaching relaxation, arguing:

(i) A revision (rather than a shift) of the cut-off date is necessary in the light of new information which tips the balance of interests between pro and con parties achieved in the 2002 Stem Cell Law.

(ii) The embryo-protective intent, under which the cut-off date became policy, can be satisfied equally effectively by different measures.

(iii) A revision is permissible because, in 2002, a compromise rather than a unanimous resolution of diverging opinions had been reached.

\section{Method}

The hESCR debate can most generally be described as an instance of pro and contra or conductive argumentation (Bell 1995, Govier 1987, 1999, 2005, Wellman 1971). We employ Wohlrapp's (2008) analyst-intervention method and orient the evaluation towards the question: Can the NEC argument "travel" (Rehg 2009) beyond its context of origin, specifically: Is it acceptable in the public context? Our answer is negative.

We first identify the argument in its strongest form (reconstruction/interpretation), then confront it with the strongest known counter-considerations (evaluation by intervention). The aim is to ascertain, in a manner that is relevant to the case, whether an objection remains without a neutralizing rebuttal. Thus, the evaluative result is a function of objections not countered by what the text (by itself) or the analyst (by enriching/projecting it) might provide. Although the evaluative result is definite, it is by no means final. Evaluations remain open to revision in a strict sense: Either no rebuttal is known or a revision of an evaluative result is necessarily called for.

Such analyses demand substantial engagement with a case. Although analysts can, to some extent, always control their involvement, it is perhaps not possible to remain "completely outside" of a debate. Following Rehg (2009), to not level the participant-analyst distinction the analyst engages primarily by way of the argumentation theoretic categories used or cited by the participants. She does not engage through taking a stance with regard to facts or norms (e.g., on the nature of stem cells or the ethical permissibility of their research use). Practically, this means that the identity of an 
argument either arises immediately from the text or any proposal for its enrichment/projection must be supported by the text or context, and remains open to doubt.

Difficulties beset explaining adequately how analyst interventions arise. At the same time, it is not clear that such an explanation is necessary for conducting an analysis. One might say that interventions are the expressions of an analyst's ability to judge a particular state of argumentative context. Thus, for each argument judged 'non-cogent' (in Rehg's terms) or 'invalid' (in Wohlrapp's terms), at least one objection has not been adequately countered. Sound analyst-judgment thus depends primarily on acquiring sufficient insight into a case. Consequently, the investment demanded of a reader is inversely proportional to her familiarity with it.

It might be perceived as a drawback that evaluations by analyst-intervention do not necessarily lead two analysts to the same result, as opinions about the sufficiency, acceptability or relevance of an objection may diverge. This makes the method susceptible to unreliability because it is non-reproducible. A weaker standard than reproducibility is adopted, namely comprehensibility. This means that it is sufficient that a second analyst understands the content and function of an intervention. When this is not the case, her task is to detail her objections in the role of a critic. The price of definiteness, then, is the revisability of the evaluative judgment.

\section{Background}

The following provides background on the hESCR debate in Germany and details the disagreement between pro and con parties. We described above the genesis of the cut-off date (the policy measure the NEC majority wishes to abolish), and we summarize the structure and content of the text under study in Section 4.

Standpoints on the preferred social policy diverge to the extent that the favored solutions mutually exclude one another. Disagreement ranges over the moral status of the human embryo, and thus over the type of legal protection to be granted. Consequently there is disagreement over the permissibility of the process and the result of weighing the interests of born human beings (e.g., in future medical therapies) against a presumed right to life of an embryo qua bearer of human dignity. This disagreement can be specified to hES cells derived from "supernumerous" embryos produced for the purpose of artificial implantation in vitro prior to the $14^{\text {th }}$ day of development (early embryo). According to the con-hESCR position, an embryo is a bearer of human dignity throughout all developmental stages and is endowed with an absolute or subjective protection right (at least) from the moment egg and sperm cell inte- 
grate. $^{2}$ The pro-hESCR side favors a graded or objective protection right. ${ }^{3}$ Though becoming more protective as the embryo develops, until day 14, the protection afforded effectively stays below that enjoyed by persons, and remains weighable against rights assigned to persons (e.g., severely ill patients, their families) and things (future medical therapy).

To date, hESCR has been carried out in Germany under very restrictive conditions compared to European and international regulation (Isasi \& Knoppers 2006, Walters 2004). The cut-off date was meant to ensure that Germany provides no causal contribution to embryo destruction although hESCR is permitted on national territory. This compromise is regularly criticized as a sign of hypocrisy (e.g., Takala \& Häyry 2007: 159). After all, parliament prohibited research on hES cells derived domestically, but allowed their import (if derived abroad) under additional conditions.

The con-hESCR party could agree to these terms because no stricter condition could undo what was regarded an impermissible harm suffered irremediably by embryos whose stem cells now become legally importable goods. Moreover, it is the character of national law to be internationally impotent. Therefore, the purpose of the Stem Cell Law had been confined "to prevent demand in Germany from causing the derivation of embryonic stem cells or the production of embryos with the aim of deriving embryonic stem cells" (SZG 2001: sect.1). We will meet this important consideration further below (Section 5.2) as the principle of proportionality.

The pro-hESCR party favored a more relaxed regulation, but could accept the cut-off-date-policy. The demand to provide no causal incentive to future destrucion of embryos was thereby met, while hESCR in Germany was in principle possible. This limited possibility sufficed "to take account also of the legitimate interests of patients who may in the future expect a cure for their illnesses to result from the findings of stem cell research" (NEC 2007: 13). In 2002, the generally shared contention had been: The date chosen suffices to satisfy research-interest for years to come (Schockenhoff 2007). As we will see, this prediction proved erroneous.

2 See Krones et al. (2006) for an empirical report on criteria for the beginning of life used among both experts and laypersons in Germany. If externally valid, nidation or conception is predominantly accepted and the status assigned to human embryos is "lower" than that afforded by German law.

3 See Merkel $(2002,2007)$ for the distinction between objective and subjective protection rights as applied to hESCR. Well-entrenched in German law and reflecting (Kantian) value ethics (Wertethik), it remains without an analogue outside of this tradition. 


\section{The 2007 National Ethics Council opinion}

Detailing the NEC (2007) opinion, we now summarize its three positions, provide its structure and locate the new premise supposed to bear on the 2002 compromise. Moreover, we identify the central section of the majority opinion and specify the argumentative task, the success of which will be evaluated in Section 6.

The German National Ethics Council ${ }^{4}$ has published a sum of twelve opinions. The first (NEC 2001) and last (NEC 2007) treat the Stem Cell Law. In principle not bound to a unanimous opinion, the 2007 opinion comprises three positions, the third being supported by a single member. With a view to initiating a new debate, discussion among council members started in autumn 2006 and occurred also in response to opinions on hESCR forwarded by commissions of the federal states and the German Research Council (DFG 2006). ${ }^{5}$ The latter had begun lobbying against the Stem Cell Law in the name of the constitutionally granted freedom of research which the Stem Cell Law explicitly sought to balance against the obligation to "protect human dignity and the right to life" (SCL 2002: sect. 1).

In May of 2007, the NEC set out on the question: "[W]hether the emerging international trend of stem cell research and the experience so far gained with the Stem Cell Law constitute reasons for amending the provisions in force since 2002" (NEC 2007: 10). ${ }^{6}$ Taking the compromise as a basis rather than questioning it, the opinion "presents proposals on how individual provisions of the law can be further developed under changed conditions" (ibid.). The Council's three mutually exclusive positions agree on the compromise character of the Stem Cell Law, but diverge on its significance and consequences. The positions are referenced by the policies favored: the majority position status quo-revision (fourteen

${ }^{4}$ Founded in 2001, its members had been directly appointed by the federal chancellor. The Council formed an independent, yet heterogeneous expertgroup of "up to 25 members, who represent the scientific, medical, theological, philosophical, social, legal, ecological and economic worlds" (NEC website). Having created a legal basis in 2007, this body was superseded by the German Ethics Council (Deutscher Ethik Rat). Appointed by parliament, the group came together in summer 2008.

5 On the standards of discourse in the NEC, see the insider's view by van den Daele (2008). He reports that the council initially entertained confronting pro and con positions on hESCR. It then resorted to the pro and con groups working out their positions separately.

${ }^{6}$ Page references to the English translation are given as (NEC), to the German original as (NER). 
votes); the minority status quo-or-else (nine votes) and status quoupdate (one vote). ${ }^{7}$ We start with the (thin) majority:

\subsection{Revise the status quo. Allow wider uses of hES cells}

Summary: The cut-off date should be replaced by "practical and reliable case-by-case consideration" (NEC 2007: 49), such that the central approval authority created in the Stem Cell Law "must be satisfied that the production of the relevant cell lines was neither instigated by the [research project-]applicant itself nor otherwise effected by virtue of actions in Germany" (ibid.). Import from universally accessible stem cell banks on a non-profit basis should be allowed, but import from commercial stem cell banks prohibited. As the derivation of hES cells from embryos in Germany is already prohibited by the embryo protection act, "[ $\mathrm{t}]$ he Stem Cell Law should merely determine the action to be taken in the event of infringements of the approval requirements (...) [while] the import and use of stem cells should be permissible not only for research but also for diagnosis and treatment" (ibid.). ${ }^{8}$

\subsection{Status quo-or-else: Adhere to the cut-off date or reopen the de- bate}

Summary: Either the cut-off date should be retained and the likely marginalization of German research in this area accepted and resources invested in alternatives (e.g., research on adult stem cells), or else the debate on the fundamental normative positions, including that laid down in the Embryo Protection Law, should be reopened in order to consider "whether it might not after all be more consistent [!] to use for research the embryos and fertilized pronuclei no longer required for reproductive purposes in Germany, rather than constantly importing new hES-cells from abroad" (NEC 2007: 57). ${ }^{9}$

7 The majority lays out its position on 43 pages, the minorities take nine and six, respectively.

8 Signed by: Wolfgang van den Daele, Horst Dreier, Detlev Ganten, Volker Gerhardt, Martin J. Lohse, Christiane Nüsslein-Volhard, Peter Propping, Jens Reich, Jürgen Schmude, Bettina Schöne-Seifert, Richard Schröder, Jochen Taupitz, Kristiane Weber-Hassemer, Christiane Woopen.

9 Signed by: Eve-Marie Engels, Regine Kollek, Christiane Lohkamp, Anton Losinger, Eckhard Nagel, Therese Neuer-Miebach, Peter Radtke, Eberhard Schockenhoff, Spiros Simitis, of which three signed a supplementary position statement favoring to uphold the status quo (A.L., P.R., E.S). 


\subsection{Adhere to the status quo under cut-off updating}

Summary: With additional uses constituting a breach of the 2002 compromise and the case-by-case considerations favored by the majority being comparatively less reliable than the unequivocal cut-off date, the addition of further permitted uses for hES cells violates the 2002 compromise. It is also unclear if a political majority would be forthcoming to support a relaxation. Besides currently funding hESCR elsewhere through German EU contributions, and although future medical therapy remains uncertain, German citizens would in any case profit eventually, if the "wrong" now done elsewhere would lead to therapeutic success. To adhere to the compromise, "the setting of a later cut-off date, albeit in the past, is the appropriate means: it is adequate, takes account of the normative principles of the Embryo Protection Law and conforms to the spirit of the 2002 compromise" (NEC 2007: $64) .^{10}$

\subsection{Structure of the majority opinion}

Section I establishes that the opinion will only pertain to the Stem Cell Law, but not the Embryo Protection Law: the majority did not aim at reopening the debate. Section II states the object of legal protection (1), summarizes the position of the embryo protection act as a premise (2), argues for the principled permissibility of revising the Stem Cell Act by re-balancing objects of legal protection against each other (3), includes a reminder that no categorical ban on profiting from "wrongful acts" in other countries has been laid down in the Stem Cell Law (4), stresses that hES cells are not to be used for arbitrary purposes (5), and then draws interim conclusions (6). Section III lays out future prospects for hESCR (1), includes a reminder of the disadvantage at which research in Germany is placed by the cut-off date (2) and of the obstacles which the law's criminal provisions bring about for international co-operations involving German researchers (3), finds the permissible uses of hESCR overly restrictive (4), and claims freedom of research is violated by the Stem Cell Law (5). Section IV presents alternatives to the cut-off date measure (1), suggests provisions for additional permitted uses (2), and discusses whether the penal provision could be amended or repealed (3). Section V states the majority's recommendations (see Section 4.1).

\footnotetext{
${ }^{10}$ Signed by Hermann Bart.
} 


\subsection{New information}

Sections I, III and IV do not offer new information or argumentation beyond the state of the debate up to 2002. Section III (2) contains the only premise that could provide grounds for re-evaluating the 2002 compromise, since it alone refers to new information.

[T]he majority of the worldwide publications up to 2005 involved research with hES stem cells (...). [I]t must be deemed a worrying sign that, while applications for work with hES cells have increased worldwide, no new application has so far been submitted in Germany in 2007. Whether this situation reflects the concerned diagnosis of "stagnation" described in the Stem Cell Committee's latest activity report will perhaps only become fully clear from further developments. What is, however, certain is that the new hES cell lines developed in the last few years must not be imported and used in Germany because they do not conform to the cut-off date criterion. Yet precisely these cell lines are currently being used in experimental research in other countries; their use will eventually define what is regarded at international level as top-ranking, relevant hES cell research. Germany is excluded from the use of these stem cell lines by the cut-off date criterion. (NEC 2007: 31; my translation)

To a large extent, this is the argumentation of the German research council (DFG 2006) for a revision of the law: Pre 2002-derived hES cells are claimed to be of insufficient quality for research. ${ }^{11}$ Presently, this is the dominant expert opinion. For example, preceding the parliamentary vote in March 2008, during the meeting of the parliamentary Committee on Education, Research and Appraisal of the Consequences of Technology (CERACT 2008), Hans R. Schöler (Max Planck Institute for Molecular Biomedicine) agrees with the NEC majority when locating his grounds for an amendment of the Stem Cell Law in the availability of a new premise.

I believe that, since 2002, there are new scientific reasons to import new cell lines: Back then, we did not at all know how bad the cells were. Possibly, they are even worse now. For me, however, it is decisive that they were already bad then, but that we just didn't know it. (CERACT 2008: 10) ${ }^{12}$

${ }^{11}$ The DFG (2006) went farther: Even if researchers would only work with adult stem cells, newer hESC lines are required as a "gold-standard" to assess whether adult cells are "equally[!] toti-potent".

12 "Ich finde, es gibt seit 2002 neue wissenschaftliche Gründe, um neue Stammzelllinien zu importieren: Wir wussten damals gar nicht, wie schlecht die Zellen waren. Sie sind jetzt möglicherweise noch schlechter. Für mich ist aber 
The argumentative task of the NEC majority, then, consists in showing that the new premise can be respected without questioning either the Stem Cell Law or the Embryo Protection Law. This task is shouldered exclusively in section II (3) of the opinion. In the following comments, we restrict our attention to the argumentation forwarded there. This is certainly not the only possible way of generating an evaluation, but it avoids the alternative of having to evaluate, e.g., whether younger hES cells are indispensable for toplevel research in Germany. Not only is the answer to the latter question debated; answering it also goes beyond the scope of argumentative analysis. After all, both support and doubt are backed (only) by expert opinion. In contrast, evaluating the claim to the revisabilityof the cut-off date is exclusively a matter of evaluating the argumentation. It is in this sense that Rehg (2009) proposes that argumentation scholars relate to a case by way of the participant's use of argumentative categories (see Section 2).

\subsection{Central section}

We identify the following as the document's central section and, below, present a micro-level analysis of it, treating the sentence as a minimum unit. Before moving on to the next section, the reader might want to ask himself or herself, particularly with respect to paragraph (D), if he or she can readily identify the argument provided below.

Section II (3)

3. Permissibility of balancing objects of legal protection against each other

[A] If the compromise of the Stem Cell Law is accepted as the starting point and foundation of evaluation, it follows that, in the regulation of the import and use of hES cells, on the one hand the embryo protection criteria must not be set below the level provided for in the Stem Cell Law, and, on the other, research must not be subjected to restrictions that would have the effect of completely precluding the use of hES cells. Nor must the interest of the sick in the development of new therapies be disregarded. However, differences of opinion exist as to the consequences of these premises for the detailed provisions.

[B] To begin with, no one disputes that any system intended to be compatible with the compromise of the Stem Cell Law must retain the objective of preventing any German causal contribution to the destruction of embryos in other countries. For this reason, the production of hES cells abroad must not be "instigated" from Germany - that is to say, it must not, by any

entscheidend, dass sie damals schon schlecht waren, wir das nur nicht wussten." 
action in Germany, be carried on, commissioned or facilitated by incentives.

[C] However, opinions differ on whether the compromise represented by the Stem Cell Law is departed from if alternatives to the present cut-off date criterion or threat of penal sanctions are considered. Some hold that these two provisions do not in themselves constitute the objective and purpose of the Stem Cell Law, but are simply means of achieving its objectives and purposes. The cut-off date criterion is intended, as provided in Section 1 No. 2 of the Stem Cell Law, to prevent the derivation of hES cells from being instigated as a result of action in Germany, whereas the criminalization provision has the aim of ensuring that the conditions for approval are observed. In the opinion of others, the cut-off date criterion is one of the essential ends of the Stem Cell Law. In their view, the compromise achieved in the Law would no longer be respected if the cut-off date were to be modified or replaced. [end. p. 15]

[D] This position is no doubt underlain by the assumption that the risk of the production of hES cells being "instigated" by action in Germany would be increased in the event of a departure from the present criterion of a fixed cut-off date. In this connection, however, it is not enough to maintain that concessions on the cut-off date might in effect be perceived as a signal of symbolic support for researchers who produce hES cells in other countries. Symbolic reinforcement of this kind cannot validly be adduced as an instance of the "instigation" of the production of hES cells within the meaning of the Stem Cell Law. Experience has shown that it cannot be assumed that such an incentive would automatically arise if the current cut-off date criterion were dropped because this would create the abstract possibility of using the new cell lines in Germany as well as abroad. The development of new cell lines in other countries is part of a dynamic that proceeds without regard to what is happening in German research. Rather than speculating on a conceivable demand for hES cells in Germany, scientists are in fact pursuing perceived research goals, strategies and opportunities. The fixed cut-off data criterion surely has the sole function of reliably precluding any concrete instigation of the production of new hES cell lines in other countries. Conversely, with regard to the extent to which new hES cell lines are produced abroad - apart from the conceivable case of such instigation-it is immaterial whether or not the cut-off date criterion is retained in Germany. For this reason, the indispensability or otherwise of the cut-off date criterion depends on the possible existence of regulatory alternatives capable of equally reliably precluding the concrete instigation, by means of action in Germany, of the production of hES cell lines in other countries.

[E] However, the legislative history of the Stem Cell Law suggests that it was actually only the strict cut-off date criterion and the symbolic signal to society of the threat of a severe penalty that persuaded some deputies to vote for the bill. Perhaps 
74 Frank Zenker

these provisions did in this way make some contribution to achieving "peace" in the dispute about the import and use of [end p. 16] embryonic stem cells. It may nevertheless be doubted that the strict cut-off date criterion is an integral component of the compromise defined in the Stem Cell Law. An argument against this idea is that eventually no one in Germany would any longer be able to take part in research with hES cells on the level of international science if the cut-off date really were set in stone (on this point, see Section III.2 below). The Stem Cell Law would then not be a compromise, but simply a deferred complete abandonment of the import and use of hES cells. Such an interpretation can surely not be reconciled with the other declared objective of the Law - that of ensuring the freedom of research. If the compromise character of the Stem Cell Law is taken seriously, the cut-off date criterion cannot be deemed indispensable. This is also implicitly conceded by those who oppose changes to the cut-off date criterion by arguing that science does not in fact need the new cell lines. Anyone who rejects a change in the cut-off date criterion on the grounds that it is not necessary at least does not rule out the possibility of the criterion being modified if this is necessary. [end of section, $\mathrm{p}$. 17] (NEC 2007: 15-17, official translation)

\section{Analysis}

We provide a micro-level analysis of the above text which distinguishes between a preparatory step and two main parts. Summarizing once, we quote verbatim and offer a critical commentary at each step. Moreover, we demonstrate why an argumentative step can (and here does) comprise more than one sentence. Critical questions with respect to the acceptability of the premises or the transition from premises to conclusion are associated with each step. Evaluation occurs largely within the commentary. In Section 6 , below, we summarize and justify this evaluation.

Our reconstruction is an interpretation based primarily on conditional relevance (Schegloff 1968). The guiding assumption is that sentences in co-location are linked by relevance relations and that, when taken together, these relations yield insight into the text's argumentative structure. In the spirit of ethno-methodology (Rehg 2009: 213-240), we understand relevance as a participant category the successful employment of which does not require a prior conceptual analysis.

Lengthy quotation may be perceived as over-effort. However, to motivate a principally revisable result (see Section 2), the analyst should make her evaluation as strong as possible, to offer her critic the basis for attempting to revise it. This aim recommends a micro-level analysis, where the use of summaries and glosses is normally a hindrance. Our interpretation does not claim to yield the 
exact argumentative structure which the text's author(s) intended. At most, argumentative analysis offers a plausible projection or enrichment. It cannot provide insight into mental states.

\subsection{Concession, difference of opinion, opponent}

In paragraph $\mathrm{A}$, the majority declares that it will not question the Embryo Protection Law. The concession is that one must accept "the compromise of the Stem Cell Law (...) as the starting point and foundation of evaluation" (NEC 2007: 15), yielding two constraints $(\mathrm{C} 1$ and $\mathrm{C} 2)$ for a permissible balancing of objects of legal protection. $^{13}$

(C1) The embryo protection criteria must not be set below the level provided for in the Stem Cell Law.

(C2) Research must not be subjected to restrictions that would have the effect of completely precluding the use of hES cells, nor must the interest of the sick in the development of new therapies be disregarded. (see NEC 2007: 15)

The next paragraph, $\mathrm{B}$, renders $(\mathrm{C} 1)$ more precise via the notion of causal contribution:

(0) [A]ny system intended to be compatible with the compromise of the Stem Cell Law must retain the objective of preventing any German causal contributions to the destruction of embryos in other countries. For this reason, the production of hES cells abroad must not be 'instigated' from Germany - that is to say, it must not, by any action in Germany, be carried on, commissioned or facilitated by incentives. (NEC 2007: 15)

In (0), constraint $(\mathrm{C} 1)$ is specified negatively, thus validating the pro/con structure. Next, the difference of opinion (DO) is located as a yes-or-no question on:

(DO) [W] hether the compromise represented by the Stem Cell Law is departed from if alternatives to the present cut-off date or threat of penal sanctions are considered. (NEC 2007: 15)

${ }^{13}$ The section headline runs "Permissibility of balancing objects of legal protection against each other" (Zulässigkeit der Abwägung zwischen den Schutzgütern). However, this section does not provide argumentative support for a principled permissibility of such balancing. It seeks to establish the permissibility of a particular (re-)weighing of objects of legal protection to ensure (perhaps reclaim) a future state of balance by integrating a new premise: Younger cell lines are needed. 
This makes arguments pro hESCR and rebuttals of con arguments conditionally relevant. A preparatory step, in paragraph $\mathrm{C}$, pertains to the pragmatic status of the cut-off date and the penal sanctions. In anticipation, it can be summarized as follows:

(1) Like the penal sanctions laid out in the Stem Cell Law, the cutoff date is either (i) a means and therefore a revisable part of the law that respects the compromise achieved in the law, provided alternative and equally reliable means for protection are available, or (ii) (at least) one of the ends of the law, therefore an integral and unrevisable part of the compromise (see NEC 2007: 15).

Comment: This exclusive and exhaustive disjunction is crucial. Assenting to the second disjunct precludes implementing a revision of the compromise, and thus constitutes the standpoint of the strongest opponent. Unless means vs. ends can be declared a nonexhaustive disjunction, the premise is acceptable. It is clear that the majority opinion is inconsistent with (1 ii), above. Now, the opponent $(\mathrm{OP})$ is construed to maintain:

(OP) [i] The cut of date criterion is one of the essential ends of the Stem Cell Law. (...) [ii] [T] he compromise achieved in the law would no longer be respected if the cut-off date were to be modified or replaced. (NEC 2007: 15)

Consequently, what immediately follows is conditionally relevant with respect to providing grounds for rejecting the second disjunct in (1).

\subsection{Part 1: Keeping concrete instigation risk constant under change of measures}

Spelling out the opponent position to be addressed in paragraph D, the text continues:

(2) [i] This position is no doubt underlain by the assumption that the risk of the production of hES cells being "instigated" by action in Germany would be increased in the event of a departure from the present criterion of a fixed cut-off date. [ii] In this connection, however, it is not enough to maintain that concessions on the cut-off date might in effect be perceived as a signal of symbolic support for researchers who produce hES cells in other countries. (NEC 2007: 16)

Comment: In (i) the opponent's position is presented as being (at least also) supported by the assumption that the departure from the cut-off date leads to an increase in the instigation-risk of hES cell 
production abroad. Moreover, as an insufficient reason for a presumed instigation-risk increase, (ii) states that a change of criteria in Germany may be perceived as a signal of symbolic support for $\mathrm{hES}$ cell producers abroad. This move fails to adequately construe (and, therefore, does not address) the de facto strongest opponent position. The latter can be rendered as the standpoint: The cut-off date is an end of the law, not a means (see OP, above). Instead, a weaker opponent is addressed. Her position is construed to be based on the rationale of a risk-increase that measures which are alternatives to the cut-off date might entail.

Subsequently, in paragraph $\mathrm{D}$, the majority denies that the relevant risk cannot be held constant under a change of measures. It is claimed that at worst the risk to be controlled by the cut-off date will remain constant (read: effectively equally controllable) under any change in risk control-measures. However, one thus only addresses the second rendering of the opponent standpoint, (OP ii), leaving (OP i) open. (This last point will become clear below when we run into a problem of interpretive relevance.) Further, it is denied that the opponent's alleged reason (that a change in riskcontrol measure leads to an increase in hES cell production instigation-risk abroad) provides sufficient grounds-namely grounds backed by the Stem Cell Law - for the claim that the cut-off date is an unrevisable compromise-part.

(3) [i] Symbolic reinforcement of this kind cannot validly be adduced as an instance of the "instigation" of the production of hES cells within the meaning of the Stem Cell Law. [ii] Experience has shown that it cannot be assumed that such an incentive would automatically arise if the current cut-off date criterion were dropped because this would create the abstract possibility of using the new cell lines in Germany as well as abroad. (NEC 2007: 16)

Comment: This step seeks to establish that the symbolic effect that the act of adopting an alternative to the cut-off date could bring about cannot qualify as an instance of the kind of instigation that is precluded by the Stem Cell Law. To this end, a distinction (to be exploited below) is introduced: instigations may be qualified as either concrete or abstract. In the absence of argumentative indicators, we rely solely on the maxim of conditional relevance. Thus, that the act of changing the cut-off date does not qualify as a concrete instigation, stated in (i), above, is supported in (ii) by the absence of experience which would confirm an automatic coming about of concrete instigation as a consequence only of changing to an equally efficacious alternative. (The term "automatically" in (ii) is challenging with respect to a charitable interpretation. See below). 
The argument would lead to its conclusion in (i), if we could assume that non-derivable consequences are false-permissible, for example, in default logic via the negation as failure-rule. However, it can be asked critically: Does not the absence of experience appealed to here find a trivial explanation in the use of automatic effectuation? On this reconstruction one can ask critically: Why, if it is never experienced, introduce direct mono-causality as the relation between a policy change and its effect on hES cell producers which licenses a transition to the conclusion argued for?

Raising this question, one would deal with argumentation that seeks to reject illegitimately an opposing standpoint by construing its defense to depend on accepting contrary-to-fact conditions. This hostile interpretation is incompatible with the expert status we can assign to the text's author(s). We face the same problem with (4).

(4) [i] The development of new cell lines in other countries is part of a dynamic that proceeds without regard to what is happening in German research. [ii] Rather than speculating on a conceivable demand for hES cells in Germany, scientists are in fact pursuing perceived research goals, strategies and opportunities. (NEC 2007: 16)

Comment: Premise (i), if true, would owe its truth at least also to the strict regulation implemented in Germany, to begin with. It is not clear whether (i) becomes false if a status quo-relaxation brings about a German participation of international scope. (ii), even if true, would then remain irrelevant. Again, the less than charitable interpretation above demands that we can clearly state the relevance of (i) and (ii).

I suggest that we are dealing with an excellent (teaching) example of interpretive irrelevance. Our failure to interpret steps (3) and (4) charitably suggests (to me) that they must not be treated separately. Rather, one should reconstruct the text such that (4) completes (3) by providing a description of the 'ability of hES cell producers abroad to be instigated by abstract possibilities'. In (3) and (4), it is claimed that there is no experience of this "ability." This reconstruction in place, the relation to the next sentence can be interpreted without difficulty: together, (3) and (4) provide support for (5):

(5) The fixed cut-off data criterion surely has the sole function of reliably precluding any concrete instigation of the production of new hES cell lines in other countries. (NEC 2007: 16; italics added)

Comment: Again (5) would beg the question when interpreted as forwarded in response to both parts of (OP) (see 4 i). After all, (5) declares that the cut-off date has a function. This is irrelevant with 
respect to the claim that it is an end. Moreover, the German version of (5) - rendered as $\left(5^{\prime}\right)$ - is stronger than what is captured by surely:

(5') The fixed cut-off data criterion can only be seen to have the sole function of reliably precluding any concrete instigation of the production of new hES cell lines in other countries. (see NER 2007: 11; italics added, my translation $)^{14}$

$\left(5^{\prime}\right)$ is stronger than (5), because it is not merely claimed that the cut-off date surely has the ascribed function. Rather, one can conclude only this, given (4). If pressed, this move can be supported by analogy to the legal principle of proportionality (PP):

(PP) A measure $M$ employed with intent $I$, e.g., to achieve function $F$, is impermissible, if a less drastic and available measure $M^{*}$ already achieves $F$.

Consider: If a change in measures would lead only to a risk increase with respect to abstract instigation, and abstract instigation is irrelevant for embryo-"production" abroad, then the Stem Cell Law cannot intend to prevent abstract instigation. Hence, (5) is forwarded as the correct legal interpretation of the experiences stated in (3 ii) and (4). So, (5) supports the claim: Given the proportionality principle (PP), the Stem Cell Act could only have been intended to preclude acts of concrete instigation, not of abstract instigation, because symbolic reinforcement (i.e., abstract instigation) is not experienced to lead to an increased risk in concrete instigation of hES cell production abroad. And that much, then, is stated in the following:

(6) Conversely, with regard to the extent to which new hES cell lines are produced abroad - apart from the conceivable case of such instigation - it is immaterial whether or not the cut-off date criterion is retained in Germany. (NEC 2007: 16)

Comment: By itself, (6) is merely a slight variation (repetition) of (4 i). On a charitable interpretation, however, it amounts to claiming that a revision of the cut-off date criterion can at most lead to a difference in abstract instigation which, in turn, remains without consequence for concrete instigation. Finally, this provides grounds for (7):

14 "Man wird die Funktion der festen Stichtagsregelung nur darin sehen können, jede konkrete Veranlassung der Herstellung von neuen HES-Zelllinien im Ausland sicher auszuschließen" (NER 2007: 11). 
(7) For this reason, the indispensability or otherwise of the cut-off date criterion depends on the possible existence of regulatory alternatives capable of equally reliably precluding the concrete instigation, by means of action in Germany, of the production of hES cell lines in other countries. (NEC 2007: 16)

Comment: (7) is the conclusion aimed at. It would be but a restatement of the first disjunct of (1), if we related it to the full opponent position, (OP i \& ii). However, (7) builds on (6). As a criterion for remaining within the 2002 compromise, (7) spells out that only concrete risk remains constant in case the cut-off date is departed from.

The complete argument in paragraph $\mathrm{D}$, then, is the following:

(A) The cut-off date is not an unrevisable part of the compromise, because equally reliable regulatory alternatives can respect the compromise character of the Stem Cell Law on the condition that only an increase in concrete instigation-risk is to be avoided which, in turn, is supported by claiming proportionality to hold with respect to the embryo-protective intent underlying the Stem Cell Law, given a null-experience with respect to the concrete effects of symbolic reinforcement on hES cell producers abroad automatically brought about by a change in measures.

The major objection to (A), which is the result of (2)-(7), is that it fails to address the opponent's full standpoint. (2)-(7) may address someone with an interest in risk-non-maximization only with respect to concrete instigations of hES cells abroad. But why would she have concerns to begin with?

We saw that the majority counters the risk of abstract instigation by claiming that, next to abstract instigation being ineffective in the concrete sense (trivial), avoiding an increase in the risk of abstract instigation cannot have been among the purposes of the Stem Cell Law, while a risk-increase in concrete instigation can be avoided by means of equally efficacious measures. At this point, it is neither necessary nor recommendable to evaluate (i) if the proposed alternative measures are in fact equally efficacious, or to evaluate (ii) if the proportionality principle supports the transition from facts to norm (see Section 4.5). Aligning this analysis with the argumentative participant-categories (see Section 2), rather than any empirical or normative facts evoked by them, one may ask: Cannot the prevention of abstract instigation have been among the purposes of the Stem Cell Law (see below)? 
First, we turn to the second part of the council's argumentation which addresses (OP i): The cut-off date is one of the essential ends of the Stem Cell Law.

\subsection{Part 2: The cut-off date is an end of the compromise}

The status quo-relaxation sub-standpoint in (7) (the cut-off date is a revisable compromise part) would be established only if the second disjunct in (1) (cut-off date is an end) can be rejected. Based on the reasons offered so far, it cannot. As shown above, (2)-(7) exclusively address the second part of the opponent's position (OP ii) (see 4.i). This is implicitly conceded in paragraph E, where the majority addresses the first part. They take up the objection that it is not enough to argue against (OP ii):

(8) However, the legislative history of the Stem Cell Law suggests that it was actually only the strict cut-off date criterion and the symbolic signal to society of the threat of a severe penalty that persuaded some deputies to vote for the bill. Perhaps these provisions did in this way make some contribution to achieving "peace" in the dispute about the import and use of embryonic stem cells. (NEC 2007: 16f.)

Comment: Note that it is not the disjunct to be rejected (the cut-off date is an end), nor a consequence thereof (the cut off-date is an unrevisable part of the compromise), but rather it is the strictness of the cut-off date (note the "Perhaps" in (8)) that is said to have provided "some contribution" on the part of the con-hESCR party to accept the compromise in the interest of peace. In spite of the "Perhaps" (which, if not deleted, rendered the premise a hypothesis rather than a claim), the above is in any case an under-description. Achieving peace may, at most, have been a secondary objective. Unless one assumes self-deception on behalf of the con-hESCR party, the protection of embryos (from research use) must count as the primary objective.

(9) [i] It may nevertheless be doubted that the strict cut-off date criterion is an integral component of the compromise defined in the Stem Cell Law. [ii] An argument against this idea is that eventually no one in Germany would any longer be able to take part in research with hES cells on the level of international science if the cut-off date really were set in stone (on this point, see Section III.2 below). (NEC 2007: 17) ${ }^{15}$

${ }^{15}$ Here, the council refers to the quote cited above as containing new information (see Section 4.5). 
Comment: While (i) merely restates the conclusion aimed for, (ii) draws a consequence claimed to follow from the cut-off date being an integral part of the compromise. The consequence is the "deferred complete abandonment" mentioned in (10), below: Eventually, hESCR "on the level of international science" would become impossible in Germany. Clearly, the cut-off date is incompatible with research-consumption of hES cells derived after the cut-off date, while such cells are currently consumed internationally. Hence, at the time of writing, the term eventually was false; the consequence was already the case. In anticipation of criticism to follow, it is rather the evaluation of this consequence which changed as research progressed. The import-ban on post-2002 derived hES cells had been evaluated as acceptable in 2002, but no longer is. It stands to reason that a change in evaluation on behalf of the pro-hESCR party had been foreseen by the con party at the time of the compromise (see Section 6).

(10) [i] The Stem Cell Law would then not be a compromise, but simply a deferred complete abandonment of the import and use of hES cells. [ii] Such an interpretation can surely not be reconciled with the other declared objective of the Law - that of ensuring the freedom of research. [iii] If the compromise character of the Stem Cell Law is taken seriously, the cut-off date criterion cannot be deemed indispensable. (NEC 2007: 17)

Comment: In (i), that this state of affairs is irreconcilable with the declared objective of ensuring the freedom of research is supported by appealing to the meaning of 'compromise'. The proponent of the status quo-relaxation standpoint can be construed as being committed to the following thesis $(\mathrm{T})$ :

(T) A compromise component agreed to between parties at time $t$ cannot have been an integral part of the compromise if, at a later time $t$, the evaluation of its consequence(s) by a participating party changes from acceptable to unacceptable.

(T) is challenging, because a later event is claimed to determine the mereological character of an earlier event, constituting an appeal to a generally non-accepted direction of causality. Moreover, that the deferred abandonment-interpretation cannot be reconciled with the objective of ensuring freedom of research, as claimed in (ii), is also problematic. It is claimed, but not supported independently of (i). After all, the 2002 compromise had been claimed to reconcile very well freedom of research with protective intent. The difficulty lies not merely in the reconciliation of these two objectives simpliciter. 
The pro-hESC party claims that embryo protection and freedom of research are not weighed proportionally, i.e., not reconciled in the right way. What this means precisely remains unclear, as descriptive proportionality can easily be achieved, given numbers. Hence, criteria for (or specifications of) normatively correct proportionality are needed. Yet, only negative ones are offered, e.g., the complete abandonment of hES cell research in Germany is incompatible with normatively correct proportionality.

Finally, (iii) presents the (otherwise unsupported) associated conditional that, upon acceptance of the antecedent, would complete the argument in such a way that it satisfies the form of a truth preserving transition among premises.

(11) [i] This is also implicitly conceded by those who oppose changes to the cut-off date criterion by arguing that science does not in fact need the new cell lines. [ii] Anyone who rejects a change in the cut-off date criterion on the grounds that it is not necessary at least does not rule out the possibility of the criterion being modified if this is necessary. (NEC 2007:

17)

Comment: In (i), the dispensability of the cut-off date criterion is presented as a premise that is shared by (at least some among) the opponent-party, as revealed by their objection that the import of post-2002 derived hES cells is not necessary for research. However, (i) addresses only opponents who are not committed to the non-dispensability of the criterion. Therefore, the generalization to anyone in (ii) fails to address the strong opponent position, according to which dispensing with the criterion (besides not being possible without violating the compromise) is unnecessary, because newer cells are not needed.

Having provided a micro-level reconstruction cum critical commentary for the central section of the NEC (2007) majority opinion, our evaluation in the next section can be comparatively brief.

\section{Evaluation}

The council's majority position fails to be established argumentatively for two reasons: Part 1 does not address the strongest opponent (Section 5.2). Part 2 relies on an assumption about the dynamic behavior of a compromise-part under change-conditions that is unsupported (Section 5.3). We will discuss the latter with respect to a more general distinction between two types of compromise below (Section 7). 


\section{Frank Zenker}

In the case at hand, the pro-argumentation ends in a conclusion which must be presupposed, namely: The cut-off date is not an integral part of the compromise and is therefore replaceable by equally reliable measures without violating the compromise achieved in the Stem Cell Law. However, we had assumed (in Section 4.5) that the task of the status quo-relaxation group consists in establishing this premise, not in presupposing it. Hence, even if one accepted that "newer" stem cells are indispensable to enable hESC research in Germany at an international level - the only new information versus the 2002 compromise-it is nevertheless clear that this cannot be achieved without either violating the compromise or falling behind the embryo protection act. Presumably, similar reasoning motivates the status quo-or-else position (Section 4.2).

Including information on the genesis of the Stem Cell Law does not improve the prospects of the status quo-relaxation standpoint. The law had been submitted to the lower house of parliament along with a four-and-a-half-page commentary. With respect to regulating "permissible research using embryonic stem cells" it stated:

Article 5 limits research on embryonic research to high-priority research aims. At the same time, only such projects are permissible whose conduct with alternative methods, according to the research project's concretely planned research question, do not allow results of equal value to be expected. In this way, the demand for embryonic stem cells by researchers working in Germany shall be limited to a minimum. Thereby, also the danger of an eventual request of a further relaxation of the legal provision possibly arising shall be opposed from the outset. (German Lower House of Parliament, printed matter 14/8394: 9; italics added, my translation $)^{16}$

The first sentence may need interpretation, but the last does not. This means that part 1 of the majority's argumentation (Section 5.2) under-construes not only the strongest known opponent position, but also the known legal basis. Of course, what is stated in the commentary may not have provided the (true) motivating reasons for MPs to assent to the law. However, such a conjecture finds no

16 $\$$ begrenzt die Forschung an embryonalen Stammzellen auf hochrangige Forschungsziele. Zugleich sind nur solche Arbeiten zulässig, deren Durchführung mit alternativen Methoden nach der in dem jeweiligen Forschungsvorhaben konkret vorgesehenen Fragestellung keine gleichwertigen Ergebnisse erwarten lässt. Auf diese Weise soll die Nachfrage in Deutschland tätiger Forscher nach embryonalen Stammzellen auf ein Mindestmaß beschränkt werden. Dadurch soll auch der Gefahr einer möglicherweise entstehenden künftigen Forderung nach einer weiteren Öffnung der gesetzlichen Bestimmungen von vorneherein begegnet werden. 
support in the following quote from Eberhard Schockenhoff (2007), deputy chair of the National Ethics Council:

Among us, the interpretation of the Stem Cell Law had been contested. The fourteen [members of the majority in the 2007 German National Ethics Council] interpret it in such a way that the issue had merely been to prevent the German demand from providing a causal incentive to the killing of embryos abroad. But that was not the only motive. A large number of members of parliament who did then [in 2002] agree to the compromise were of the opinion that the stem cell lines are stable and that one could therefore satisfy research-needs in the long term. They argued that the wrong constituted by the killing of embryos, from which stem cells are generated, although regrettable, cannot be undone by refraining from research. But this now changes. One can regret a past wrong. But if one foresees that ever new wrongs are being committed in order to gain new stem cell lines, then credibility is lost. Then we deal with an institutionalized double-standard of morality. (Schockenhoff 2007; my translation $)^{17}$

It is not necessary to evaluate whether members of the status quorelaxation position entertain a double standard of morality. It is sufficient to point out that, in 2002, a non-negligible number of MPs saw in the cut-off date an integral part of the compromise. This is the place to state that the argumentation reviewed here cannot travel beyond its local context, because it lacks what Rehg (2009) calls content merits. After all, to deem the reasons offered by the council's majority sufficient for a relaxation of the status quo (in the sense of being acceptable reasons outside of this group), one has to disregard the explicitly voiced intent of protecting embryos, thus disregard a condition under which the law had been passed by a parliamentary majority in Germany. To get "leverage", the NEC majority invoked (or presupposed) a thesis, (T), on the semantics of compromise (Section 5.3). At best, $(\mathrm{T})$ is supported by prag-

${ }^{17}$ Die Interpretation des Stammzellgesetzes war unter uns strittig. Die vierzehn interpretieren es so, als sei es damals nur darum gegangen auszuschließen, dass von der deutschen Nachfrage nach Stammzelllinien ein kausaler Anreiz zur Tötung von Embryonen im Ausland ausgeht. Das war aber nicht das einzige Motiv. Sehr viele Abgeordnete, die damals dem Kompromiss zustimmten, waren der Auffassung, dass Stammzelllinien stabil seien und dass man daher mit den damals vorhandenen Stammzelllinien den Forschungsbedarf auf sehr lange Sicht würde abdecken können. Sie argumentierten, dass das Unrecht, das in der Tötung der Embryonen besteht, aus denen Stammzellen gewonnen werden, zwar bedauerlich, aber durch einen Forschungsverzicht nicht mehr ungeschehen zu machen sei. Aber genau dies ändert sich jetzt. Man kann vergangenes Unrecht bedauern. Aber wenn man voraussieht, dass immer neues Unrecht begangen wird, um neue Stammzelllinien zu gewinnen, dann ist es mit der Glaubwürdigkeit vorbei: Dann handelt es sich um eine institutionalisierte Doppelmoral. 
matic consequences that do not entail its unacceptability. (T) appeals to an odd direction of causality and this move remains in need of support. Therefore, the status quo-relaxation standpoint fails to be established. Insofar as the status quo-update standpoint depends on accepting that the cut-off date is not an integral part of the compromise, it likewise fails to be established.

We are left with the status-quo-or-else standpoint. As a recommendation, it has pragmatically either already undercut itself or it recommends, as a next step, halting and doing nothing or else debating. Again pragmatically, this comes out as the iterated use of the OR-connective on any set of sentences except the stem cell and the Embryo Protection Law. One easily reads ridicule into the last disjunct. However, the standpoint is not stronger. Likewise, it seems wrong to downplay that some among those opting for the status quo-or-else standpoint prefer the option of halting (Section 4.3). Others claim that stem cell research and the Embryo Protection Law are jointly inconsistent (Section 4.2)

In sum, the argumentation that was here reconstructed and evaluated does not achieve a cogent justification of the majority's opinion in the sense of providing an argument which remains without objection once its local context is extended to relevant neighboring contexts (Rehg 2009: 278, Wohlrapp 2008). By implication, this verdict may extend to the 2008 majority of German parliament which shifted the cut-off date ahead, insofar as this argumentation had been adopted.

\section{Discussion}

The significance, for the case at hand, of having reached the 2002 Stem Cell Law by compromise rather than unanimous decision cannot be overstressed. It is perhaps equally remarkable that the journals Argumentation, Argumentation and Advocacy, and Informal Logic have so far featured not a single article dedicated to compromise as a phenomenon that bears on argumentation theory. ${ }^{18}$ In economics, compromises are treated game theoretically as a bargaining outcome sufficing some mathematically specified characterization, e.g., pareto-(sub)optimality ${ }^{19}$ (Ramik \& Vlach 2002), under fixed goals or as a worth-function maximization over outcome states under goal adaptation (Zlotkin \& Rosenschein 1996). In real life, outcomes on which parties reach a compromise must be created. At any rate, the process involves not only mathematical means. In negotiation and conflict resolution, the notion of

\footnotetext{
${ }^{18}$ We assume that the search functions of the respective websites are reliable.

19 An outcome is pareto-optimal when no player can improve her situation without at least one player's situation thereby deteriorating.
} 
compromise has received a finer grained specification than the locally interpretable: "Actors try to find compromises that score high and relatively equally on key goal dimensions" (Goertz 2004: 16), by distinguishing principled from strategic compromises. In the latter case, "[t]he essential component of compromise, namely, mutuality, is lacking" (Cohen-Almagor 2006: 434). This distinction is helpful for characterizing our case.

The pro and con-hESCR parties are not divided over preferences, but over values (freedom of research vs. a particular understanding of human dignity). Importantly, if the two events are viewed in historical succession, then the fact-based reasoning leading the con-party to accept the 2002 compromise (hES cells already "harvested" cannot be protected by a new law) precludes assent to the subsequent revision that is motivated by the inferior quality of legally procurable stem cells. In other words, the particular reasoning provides support for a one-time-compromise, but looses credibility when iterated (see the Schockenhoff quote in Section 6). In a historical perspective, then, unlike 2002, the 2008 amendment of the Stem Cell Law can no longer count as a principled compromise.

The economic model serves to make this point clearer. In game theoretic terms, if the 2002 compromise constituted a paretooptimal outcome relative to the state of information in 2002, then any deviation produces a sub-optimal outcome relative to the same state. When compared to the 2002 outcome, given new information, not revising the prior compromise leaves the pro-side worse off. And a revision of the 2002 compromise leaves the con-side worse off. Now, whether freedom of research has effectively been weighed higher in 2008 than in 2002 or would, in the long run, be effectively weighed zero in case the 2002 compromise is not modified (so as to allow the import of newer cells), depends at least also on whether one takes a historical or a systematic view. On the latter view, the 2008 update is a distinct compromise between contrarily interested parties, given the post-2002 state of information.

To the pro-hESCR party, a revision is unavoidable to maintain the principled possibility of state of the art hESCR, because not revising isolates German research in this field internationally. To the con-hESCR party, a revision is impermissible because it entails instigating the destruction of more hES cells through research in Germany than is possible given the 2002 compromise. Evidently, the NEC majority takes the historical rather than the systematic perspective. They seek to establish that the measures alternative to the cut-off date stay within the 2002 compromise. In contrast, the status quo-or-else position could allow for a new compromise on the basis of the 2008 state of information. Thus, the perhaps greatest problem for the NEC majority consists in "having it both 
88 Frank Zenker

ways": abandon the cut-off date and understand this result to remain within the 2002 compromise.

\section{Summary and Outlook}

It was argued that the NEC (2007) majority argumentation in favor of an amendment of the 2002 German Stem Cell Law fails to establish that a replacement of the cut-off date with alternative measures can remain within the 2002 compromise between pro and con $\mathrm{hESCR}$ parties. The reasons for this negative evaluation consist, on the one hand, in the majority having underconstrued the strongest con-hESCR position. According to this strong position, the cut-off date for the legal import of hES cells is one of the essential ends of the 2002 compromise. On the other hand, the majority fails to offer support for a semantic assumption regarding the integrity of compromise parts. According to this assumption, the integrity of a compromise part is a function of the evaluative constancy of the compromise's consequences. We suggested that taking the historical rather the systematic perspective on this compromise explains the naturalness of this assumption, which the majority deems to be in no need of further support.

Taking a substantial stance on hESCR was avoided. We argued that the prospects of the pro-hESCR position improve when understanding new information to provide grounds for a new compromise rather than reasons to amend a prior compromise. This was detailed by considerations of pareto-optimality adopted from game theory. We argued that therefore the underlying problem of the NEC argumentation consists in taking a historical rather than a systematic perspective. In sum, the verdict is that the 2007 NEC majority offers argumentation which is not able to travel beyond its local context. It remains a future task to explain why one of Germany's top advisory bodies provides sophisticated, yet clearly deficient argumentation. Such work might consider this a case of bargaining (Provis 2004), rather than argument.

\section{Acknowledgements}

Earlier versions of this paper were read at a workshop in March 2008 and at the June 2009 OSSA conference at the University of Windsor, Ontario, Canada. I thank J.A. Blair, R.H. Johnson, the audiences and an anonymous reviewer for comments that helped to improve the paper. Research was partially funded by the Trans Coop Program of the Alexander von Humboldt Foundation and concluded during a postdoctoral fellowship from the Swedish Research Council at the University of Lund, Sweden. 


\section{References}

Beckmann, J. P. (2004). On the German Debate on Human Embryonic Stem Cell Research. Journal of Medicine and Philosophy 29, 603-621.

Bell, W. J. (1995). A Pragmatic Framework for the Evaluation of Policy Arguments. Policy Studies Review 14, 3-24.

Braun, K. (2005). Not Just for Experts: The Public Debate about Reprogenetics in Germany. Hastings Center Report 35, 4249.

Curzer, H. J. (2004). The ethics of embryonic stem cell research. The Journal of Medicine and Philosophy 29, 533-562.

CERACT (2008). Committee on Education, Research and Appraisal of the Consequences of Technology, 3 March 2008. Verbatim Protocol 16/53, German Bundestag, $<$ http://www.bundestag.de/ausschuesse/a18/anhoerungen/ stammzellgesetz/wortprotokoll.pdf $>$.

Daele, W. van den (2008). Streitkultur. Über den Umgang mit unlösbaren moralischen Konflikten im Nationalen Ethikrat. In: Gosewinkel, D. \& G. F. Schuppert (eds). Politische Kultur im Wandel von Staatlichkeit. Berlin: Edition Sigma, 357-384.

DFG/Deutsche Forschungsgemeinschaft (2006). Stammzellforschung in Deutschland-Möglichkeiten und Perpektiven, $<$ http://www.dfg.de/aktuelles_presse/reden_stellungnahmen/2 006/download/stammzellforschung_deutschland_lang_0610. pdf $>$.

Embryo Protection Law/Embryonenschutzgesetz (1990).

$<$ http://bundesrecht.juris.de/ eschg/> (English:

$<$ www.bmj.de/files/-/1147/ESchG\%20englisch.pdf $>$ ).

Geyer, C. (ed.) (2001). Biopolitik. Die Positionen. Frankfurt a.M.: Suhrkamp.

Govier, T. (1987). Problems in Argument Analysis and Evaluation (Studies of Argumentation in Pragmatics and Discourse Analysis 5). Berlin: Mouton de Gruyter.

Govier, T. (1999). Reasoning with Pros and Cons. In: The Philosophy of Argument. Newport News, VA: Vale Press, chapter 10.

Govier, T. (2005). A practical Study of Argument (6 $6^{\text {th }}$ ed.). Belmont, CA: Thomson.

Goertz, G. (2004). Constraints, Compromises and Decision Making. Journal of Conflict Resolution 48, 14-37.

Knoppers, B.M., S. Bordet \& R. Isasi (2008). The Human Embryo: Ethical and Legal Aspects. In: Lafond, J. \& C. Vaillancourt (eds). Human Embryogenesis: Methods and Protocols (Methods in Molecular Biology, Vol. 550). New York: Springer (Humana Press), 281-305. 
90 Frank Zenker

Krones, T. (2006). The Scope of the Recent Bioethics Debate in Germany: Kant, Crisis, No Confidence in Society. Cambridge Quarterly of Healthcare Ethics 15, 273-281.

Krones, T., E. Schlüter, E. Neuwohner, S. El Ansari, T. Wissner \& G. Richter (2006). What is the preimplantation embryo? Social Science \& Medicine 63, 1-20.

Merkel, R. (2002). Forschungsobjekt Embryo. München: DTV.

Merkel, R. (2007). The legal status of the human embryo. Reproductive Biomedicine Online 14, supplement 1, 54-60.

NEC/Nationaler Ethik Rat/German National Ethics Council (2001). Stellungnahme zum Import menschlicher embryonaler Stammzellen. $<$ http://www.ethikrat.org /archiv/nationalerethikrat/stellungnahmen/pdf/ Stellungnahme_Stammzellimport.pdf $>$

NEC/NER/Nationaler Ethik Rat/German National Ethics Council (2007). Zur Frage einer Änderung des Stammzellgesetztes. $<$ http://www.ethikrat.org/archiv/ nationalerethikrat/stellungnahmen/pdf/Stn_Stammzellgesetz.pdf $>$ (English:

$<$ http://www.ethikrat.org/_english/publications/Opinion_Sh ould the_Stem_Cell_Law_be_amended.pdf $>$ ).

Provis, C. (2004). Negotiation, Persuasion and Argument. Argumentation 18, 95-112.

Ramik, J. \& Vlach, M. (2002). Pareto-optimality of compromise decisions. Fuzzy Sets and Systems 129, 119-127.

Röspel, R. (2008). Speech to the German lower house of parliament. Parliamentary Stenographical Report, $155^{\text {th }}$ Session (11 April 2008), 16307-16308 $<$ http://dip21.bundestag.de/dip21/btp/16/16155.pdf $>$.

Rehg, W. (2009). Cogent Science in Context. The Science Wars, Argumentation Theory and Habermas. Cambridge, MA: The MIT Press.

Schegloff, E. (1968). Sequencing in conversational openings. American Anthropologist 70, 1075-1095. (Reprinted in: Gumperz, J.J. \& D. Hymes (eds) (1972). Directions in sociolinguistics. New York: Basil Blackwell, 346-380).

Schmidt, K.W., F. Jotterand \& C. Foppa (2004). Neither Convention nor Constitution - What the Debate on Stem Cell Research Tells Us About the Status of the Common European Ethics. Journal of Medicine and Philosophy 29, 499-508.

Schockenhoff (2007). Institutionalisierte Doppelmoral. Stammzellforschung: Eberhard Schockenhoff kritisiert die letzte Stellungnahme des Nationalen Ethikrates. Die Tagespost, 19 July 2007, <http://www.die-tagespost.de/archiv/ titel_anzeige.asp?ID $=33529>$.

Stem Cell Law/Stammzellgesetz (SCL).

$<\mathrm{http}$ ://bundesrecht.juris.de/stzg/index.html $>$ (English: 
$<$ www.bmj.bund.de/files/-

/1146/Stammzellgesetz\%20englisch.pdf $>$ ).

Stark, C. (2007). Embryonic Stem Cell Research according to German and European Law. German Law Journal 7, 665656.

Takala, T. \& M. Häyry (2007). Benefiting from past wrongdoing, human embryonic stem cell lines, and the fragility of the German legal position. Bioethics 21, 150-159.

Thompson, J. A., Itskovitz-Eldor, J., Shapiro, S. S., Waknitz, M. A., Swiergiel, J. J., Marschall, J. S. \& Jones, J. M. (1998). Embryonic stem cell lines derived from human blastocysts. Science 282,1145-1147.

Isasi, R. M. \& B. M. Knoppers (2006). Beyond the permissibility of embryonic and stem cell research: substantive requirements and procedural safeguards. Human Reproduction 21, 2474-2481.

Walters, L. (2004). Human Embryonic Stem Cell Research: An Intercultural Perspective. Kennedy Institute of Ethics Journal 14, 3-38.

Wellmann, C. (1971). Challenge and Response: Justification in Ethics. Carbondale: Southern Illinois University Press.

Wohlrapp, H. (2008). Der Begriff des Arguments: über die Beziehungen zwischen Wissen, Forschen, Glauben, Subjektivität und Vernunft. Würzburg: Königshausen \& Neumann.

Zlotkin, G. \& Rosenschein, J.S. (1996). Compromise in negotiation: exploiting worth functions over states. Artificial Intelligence 84, 151-176. 